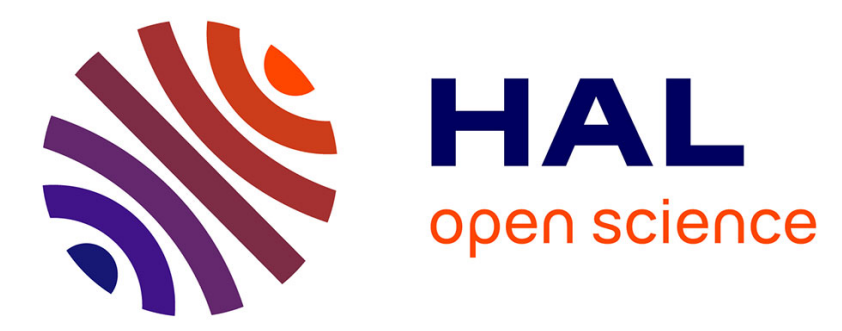

\title{
Environmental tolerance of: implications for its distribution as a marine non-native species
}

Gail V. Ashton, Kate J. Willis, Michael T. Burrows, Elizabeth J. Cook

\section{To cite this version:}

Gail V. Ashton, Kate J. Willis, Michael T. Burrows, Elizabeth J. Cook. Environmental tolerance of: implications for its distribution as a marine non-native species. Marine Environmental Research, 2007, 64 (3), pp.305. 10.1016/j.marenvres.2007.02.003 . hal-00501909

\section{HAL Id: hal-00501909 \\ https://hal.science/hal-00501909}

Submitted on 13 Jul 2010

HAL is a multi-disciplinary open access archive for the deposit and dissemination of scientific research documents, whether they are published or not. The documents may come from teaching and research institutions in France or abroad, or from public or private research centers.
L'archive ouverte pluridisciplinaire $\mathbf{H A L}$, est destinée au dépôt et à la diffusion de documents scientifiques de niveau recherche, publiés ou non, émanant des établissements d'enseignement et de recherche français ou étrangers, des laboratoires publics ou privés. 


\section{Accepted Manuscript}

Environmental tolerance of Caprella mutica: implications for its distribution as a marine non-native species

Gail V. Ashton, Kate J. Willis, Michael T. Burrows, Elizabeth J. Cook

PII:

S0141-1136(07)00036-0

DOI:

10.1016/j.marenvres.2007.02.003

Reference:

MERE 3103

To appear in:

Marine Environmental Research

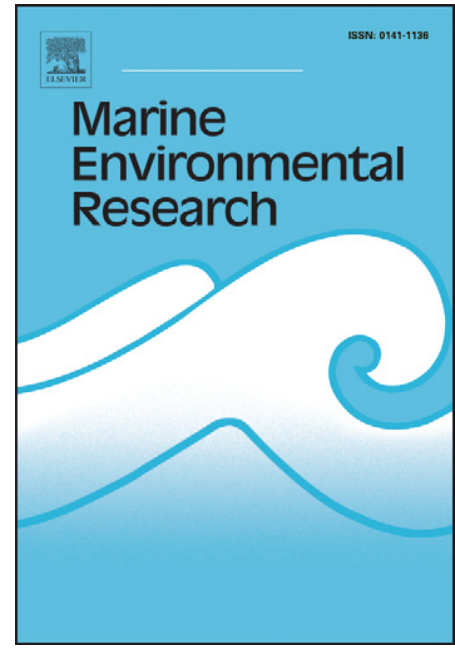

Received Date: $\quad 21$ December 2006

Revised Date: $\quad 8$ February 2007

Please cite this article as: Ashton, G.V., Willis, K.J., Burrows, M.T., Cook, E.J., Environmental tolerance of Caprella mutica: implications for its distribution as a marine non-native species, Marine Environmental Research (2007), doi: 10.1016/j.marenvres.2007.02.003

This is a PDF file of an unedited manuscript that has been accepted for publication. As a service to our customers we are providing this early version of the manuscript. The manuscript will undergo copyediting, typesetting, and review of the resulting proof before it is published in its final form. Please note that during the production process errors may be discovered which could affect the content, and all legal disclaimers that apply to the journal pertain. 
1 Environmental tolerance of Caprella mutica: implications for its distribution as a

2 marine non-native species

3

4 Gail V. Ashton, Kate J. Willis*, Michael T. Burrows, Elizabeth J. Cook

5

6 Scottish Association for Marine Science, Dunstaffnage Marine Laboratory, Oban,

$7 \quad$ Argyll, PA37 1QA, Scotland

8

$9 *$ Corresponding author:

10 Kate Willis

11 Scottish Association for Marine Science

12 Dunstaffnage Marine Laboratory

13 Oban, Argyll, PA37 1QA

14 Scotland

15

16 Tel: +44 1631559313

17 Fax: +44 1631559001

18 Email address: kjw@sams.ac.uk

19

20 
20

21

22

\section{Abstract}

Physiological tolerances limit the distribution of marine species, with geographical ranges being set by environmental factors, such as temperature and salinity, which affect the rates of vital processes and survival of marine ectotherms. The physiological tolerances of the non-native marine amphipod Caprella mutica were investigated in laboratory experiments. Adult $C$. mutica were collected from a fish farm on the west coast of Scotland and exposed to a range of temperatures and salinities for 48 h. C. mutica were tolerant of a broad range of temperature and salinity conditions, with $100 \%$ mortality at $30{ }^{\circ} \mathrm{C}\left(48 \mathrm{~h} \mathrm{LT50,} 28.3 \pm 0.4{ }^{\circ} \mathrm{C}\right)$, and salinities

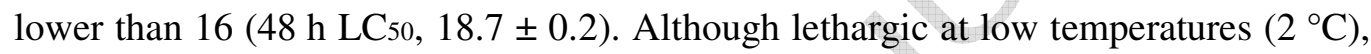
no mortality was observed, and the species is known to survive at temperatures as low as $-1.8{ }^{\circ} \mathrm{C}$. The upper $\mathrm{LC}_{50}$ was greater than the highest salinity tested (40), thus it is unlikely that salinity will limit the distribution of $C$. mutica in open coastal waters. However, the species will be excluded from brackish water environments such as the heads of sea lochs or estuaries. The physiological tolerances of $C$. mutica are beyond the physical conditions experienced in its native or introduced range and are thus unlikely to be the primary factors limiting its present distribution and future spread.

\section{Keywords}

Biological invasion, caprellid amphipod, non-native distribution, physiological tolerance, salinity tolerance, temperature tolerance 
41

42

\section{Introduction}

The marine amphipod Caprella mutica, a native of north-east Asia, is now widely distributed in the northern hemisphere between latitudes $35^{\circ} \mathrm{N}$ and $70^{\circ} \mathrm{N}$, representing a considerable extension to its native latitudinal range (Ashton et al., in press). The non-native populations discovered to date are restricted to temperate oceanic coasts that experience temperatures ranging from 0 to $22{ }^{\circ} \mathrm{C}$, similar to that of the native habitat, which has an annual seawater temperature range of -1.8 to $25^{\circ} \mathrm{C}$ (Schevchenko et al., 2004).

Environmental factors are likely to play an important role in influencing the present and future global distribution of $C$. mutica, as physiological tolerances result in ranges being set by physical characteristics that affect the rates of vital processes and survival (Vermeij, 1996). Temperature and salinity are often considered to be the principle variables affecting growth, reproduction and survival of marine ectotherms (Kinne, 1970a; Kinne, 1970b), and can act singly or in combination to influence distribution patterns (Wiederholm, 1987; Stauffer \& Boltz, 1994). Previous work has shown that while temperature does not limit the latitudinal distribution of $C$. mutica on the west coast of Scotland (Ashton et al., in press), it does influence global distribution patterns of caprellid amphipods (Laubitz, 1970; Thiel et al., 2003). For example, temperature is the primary factor limiting the distribution of caprellids in Australasia and Southern Chile (Thiel et al., 2003), and in the North Pacific (Laubitz, 1970), with most species occurring in the 10 to $15{ }^{\circ} \mathrm{C}$ temperature range, and only a few in the sub-antarctic 5 to $10{ }^{\circ} \mathrm{C}$ range. The relatively disjunctive non-native distribution of C. mutica within the region experiencing temperatures between 0 to $22{ }^{\circ} \mathrm{C}$, suggests that either range expansion is still underway, or factors other than temperature are affecting its establishment at a global scale. 
66

67

68

69

70

71

72

73

74

75

76

77

78

79

80

81

86 Methods

\section{Caprellid collection and maintenance}

88 Caprella mutica were collected from filamentous red algae attached to pontoon 89 structures at Dunstaffnage fish farm $\left(56^{\circ} 27.090^{\prime} \mathrm{N} 05^{\circ} 27.733^{\prime} \mathrm{W}\right)$ in June 2005 and 
90

2006. The animals were transported in sea water, still attached to the algae, in $10 \mathrm{~L}$ buckets. Animals were acclimatised to laboratory conditions for $48 \mathrm{~h}$ at a constant temperature $\left(14 \pm 1^{\circ} \mathrm{C}\right.$, ambient temperature) at a photoperiod of $8 \mathrm{D}: 16 \mathrm{~L}$, the photoperiod regime was maintained throughout the tolerance experiments. The buckets received constant aeration and no additional food was given.

\section{Temperature tolerance experiments}

Fifteen containers $(1.5 \mathrm{~L})$ were filled with filtered sea water $(100 \mu \mathrm{m}$; salinity $~ 35)$ and five pieces of $5 \mathrm{~mm}$ mesh $\left(150 \mathrm{~cm}^{2}\right)$ were added to each container. Larger, healthy-looking animals were carefully isolated from the algae using forceps and transferred to the mesh in the experimental containers. A maximum of 34 individuals, including at least five male and five female $C$. mutica were added to each container. Starting numbers in each container were recorded. Experimental containers were then transferred into water baths $(60 \times 30 \mathrm{~cm})$ maintained at five temperatures, with three replicate containers at each temperature. The containers reached test temperatures within 10 minutes of the start of the experiment. Temperatures were maintained using either TropicMarin heaters, or a Grant chiller, and were monitored throughout the experiment with temperature data loggers (Tinytag Aquatic, TG-3100). After 48 h, the containers were removed from the water baths and animals were immediately inspected for mortality, defined as a lack of response to mechanical stimulus (gentle prodding with a blunt probe).

A preliminary range-finding test using temperatures of $2,10,22,31$ and $40^{\circ} \mathrm{C}$ was undertaken to define approximately the lethal tolerance limits of $C$. mutica. These temperatures were selected pragmatically in an effort to include mortality rates ranging from $0 \%$ to $100 \%$. In the range finding test, caprellids exposed to $40{ }^{\circ} \mathrm{C}$ died 
115 within 5 minutes, while at $2{ }^{\circ} \mathrm{C}$ they were immobile after $48 \mathrm{~h}$, and lethargic when

116 stimulated. The second definitive experiment used a narrower range of temperatures

$117\left(21,24,26,28\right.$ and $\left.30^{\circ} \mathrm{C}\right)$ encompassing the upper lethal limit, which was estimated

118 to lie between 22 and $31{ }^{\circ} \mathrm{C}$ in the range finding test.

\section{Salinity tolerance experiments}

121 Experimental procedures and conditions were as described for the temperature

122 tolerance tests, with the exception that the salinity tolerance experiments were

123 maintained at a temperature of $14 \pm 1{ }^{\circ} \mathrm{C}$ in a constant temperature room.

124 Large healthy-looking caprellids were transferred to exposure tanks (1.5 L) containing

125 filtered sea water $(100 \mu \mathrm{m})$ at five different salinities. Salinities were achieved by

126 addition of artificial sea salt (Tropical Marin) to water treated by reverse osmosis.

127 Salinity was confirmed using a portable refractometer (Atago, S/MILL) at the

128 beginning and end of the $48 \mathrm{~h}$ exposure periods. After $48 \mathrm{~h}$, individuals were

129 inspected for mortality by gentle prodding with a blunt probe.

130 As above, a preliminary range-finding test was done using salinities of $0,10,20,30$

131 and 40 in an attempt to incorporate concentrations causing $0 \%$ and $100 \%$ mortality. In

132 the range finding test, caprellids exposed to a salinity of 0 were immobile within 5

133 minutes, with $100 \%$ mortality at salinities of 0 and 10 after $48 \mathrm{~h}$. The upper lethal

134 limit was higher than $40(<10 \%$ mortality at salinities of 30 and 40$)$. The second

135 definitive experiment employed a narrower range of salinities $(9,13,15,18$ and 20)

136 encompassing the lower lethal limit, which was estimated to lie between 10 and 20 in 137 the range finding test. 
139

140 Median lethal $\mathrm{LT}_{50}$ and $\mathrm{LC}_{50}$ values and associated $95 \%$ confidence limits were

141 calculated using probit (Finney, 1971) or trimmed Spearman-Karber analysis (TSK;

142 Hamilton et al., 1977; U.S.E.P.A., 1990) using MINITAB. MINITAB uses a Chi-

143 squared analysis $\left(\chi^{2}\right)$ to test whether the data fits the Probit model. When $\chi^{2}$ rejected

144 the Probit model $(P>0.05)$, a trimmed Spearman-Karber analysis was used to

145 calculate a non-parametric estimate of the lethal value. A disadvantage of the TSK

146 analysis is that it only yields the median lethal response $\left(\mathrm{LC}_{50}\right)$ and $95 \%$ confidence

147 limits. When the test results are not unimodal or symmetrical about the median lethal

148 response, the confidence intervals (CI) can be unreliable. A pairwise students' $t$-test

149 was used to compare differences in mortality of male and female C. mutica at each

150 temperature.

151

\section{Results}

153

154 Following $48 \mathrm{~h}$ exposure to temperatures between $21{ }^{\circ} \mathrm{C}$ and $30{ }^{\circ} \mathrm{C}$, there was a

155 marked increase in mortality of $C$. mutica at temperatures greater than $26^{\circ} \mathrm{C}$, with

$156100 \%$ mortality at $30{ }^{\circ} \mathrm{C}$ (Figure 1 ). At $24{ }^{\circ} \mathrm{C}$, mortality was increased $(\sim 25 \%)$ relative

157 to that at $26{ }^{\circ} \mathrm{C}$, and similar to mortality at $28{ }^{\circ} \mathrm{C}$. The reason for this is unknown, but

158 may be a response to other uncontrolled experimental conditions (e.g. pH or oxygen).

159 Mortality was $<10 \%$ at temperatures of $21{ }^{\circ} \mathrm{C}$ and $26{ }^{\circ} \mathrm{C}$. The $48 \mathrm{~h} \mathrm{LT}_{50}( \pm 95 \%$ C.L.)

160 was $28.3 \pm 0.4{ }^{\circ} \mathrm{C}$. There was no significant difference in mortality between male and

161 female C. mutica. 
163

164

165

166

167

168

169

170

171

172

173

174

175

176

177

178

179

180

181

184

185

186

\section{Salinity tolerance}

$100 \%$ mortality was observed following $48 \mathrm{~h}$ exposure of $C$. mutica to salinities lower than 15 (Figure 2). At a salinity of 18, individuals were lethargic and less responsive to stimulation than those at 20 . The lower $48 \mathrm{~h} \mathrm{LC}_{50}$ ( $\pm 95 \%$ C.L.) was $18.7 \pm 0.2$. The lower $\mathrm{LC}_{50}$ for females $(18.0 \pm 0.3)$ was significantly higher $(P<0.05)$ than that for males $(19.3 \pm 0.4)$

\section{Discussion}

Adult $C$. mutica collected on the west coast of Scotland were tolerant of a wide range of temperature and salinity conditions in $48 \mathrm{~h}$ laboratory exposures. The upper thermal tolerance limit of $C$. mutica $\left(48 \mathrm{~h} \mathrm{LT}_{50}, 28.3^{\circ} \mathrm{C}\right)$ was higher than maximum temperatures experienced in its non-native Scottish habitat $\left(16{ }^{\circ} \mathrm{C}\right.$; Ashton et al., in press), or in its native habitat $\left(25^{\circ} \mathrm{C}\right.$, Schevchenko et al., 2004). The lower lethal temperature was not determined as there was no mortality at the lowest temperature tested $\left(2{ }^{\circ} \mathrm{C}\right)$, although the caprellids were immobile after $48 \mathrm{~h}$ at $2{ }^{\circ} \mathrm{C}$ and were lethargic when stimulated. After $48 \mathrm{~h}$ at a salinity of $18, C$. mutica were lethargic, and at salinities lower than $16,100 \%$ mortality was observed. These salinity values are also higher than those recorded in the native and non-native habitat of the caprellid (11 and 10.5 respectively; Schevchenko et al., 2004; Ashton et al., in press).

The current experiments were run for a period of 48 hours, and therefore only give an indication of the short-term tolerance of C. mutica. However, the thermal tolerance limits recorded in this study suggest that $C$. mutica could survive introduction to the tropics or the poles, extending its current distribution. In the northern hemisphere, $C$. mutica has been introduced to both coasts of North America, from 37.5 to $48.5^{\circ} \mathrm{N}$ and 
187

188

189

190

191

192

193

194

195

196

197

198

199

200

201

202

203

204

205

206

207

to the Atlantic coasts of Europe from 49.5 to $69.1^{\circ} \mathrm{N}$. In the southern hemisphere, $C$. mutica has only been described from New Zealand (Ashton et al., in press). Sea surface temperatures at the equator are relatively stable at 26 to $27{ }^{\circ} \mathrm{C}$ throughout the year (Tait, 2001), slightly lower than the $48 \mathrm{~h}$ upper lethal limit of $28{ }^{\circ} \mathrm{C}$. However, the ability of $C$. mutica to survive prolonged exposure to high temperatures is unknown, and it is also possible that earlier life stages may not be as tolerant to high temperatures as the adults.

In its native habitat, populations of $C$. mutica survive at temperatures as low as $1.8^{\circ} \mathrm{C}$, and non-native populations have established in areas that freeze at the surface during winter, such as Passammaquoddy Bay, Canada (Ashton et al., in press). Given the lethargic state of the caprellids after $48 \mathrm{~h}$ at $2{ }^{\circ} \mathrm{C}$ in the present study, it is likely that growth and reproduction are reduced, or cease, at such low winter temperatures.

The salinity tolerance of adult $C$. mutica is similar to or slightly less than that of other Caprella species. The lower $48 \mathrm{~h} \mathrm{LC}_{50}(18.7 \pm 0.2)$ is higher than that of $C$. scaura and C. equilibria, with $24 \mathrm{~h} \mathrm{LC}_{50}$ values of 7.5 and 11.5 respectively (Cockman \& Albone, 1987), noting that these values are for $24 \mathrm{~h}$ exposures, not $48 \mathrm{~h}$. For other Caprella species, C. danilevski, C. subinermis, C. penantis and C. verrucosa, $48 \mathrm{~h}$ $\mathrm{LC}_{50}$ values ranged from 12 to 17 (Takeuchi et al., 2003). The increased salinity tolerance of male $C$. mutica in the present study may reflect the sexual dimorphism of the species (the males are considerably larger) or differences between the sexes in resource allocation to reproduction (Hoback \& Barnhart, 1996). It is surprising, however, that this trend was not observed with temperature, which might be expected to produce a greater physiological response (Davenport \& Davenport, 2005).

In the native habitat, C. mutica individuals experience salinities as low as 11 (Schevchenko et al., 2004), considerably lower than the $48 \mathrm{~h} \mathrm{LC}_{50}$ in this study. Thus, 
212 the current realized distribution of $C$. mutica with respect to salinity is beyond its

213 fundamental niche described here. This is contrary to the expectation for marine 214 ectotherms (Sprague, 1963; Tait, 2001). In coastal habitats, C. mutica are probably 215 able to survive fluctuating salinity conditions during the tidal cycle and short periods 216 of exposure to low salinity during periods of heavy rainfall. However, prolonged 217 exposure to salinity lower than 18 is likely to adversely affect the caprellid, and may 218 explain why populations are absent from the upper reaches of Scottish sea lochs that 219 regularly experience low salinities (Ashton pers. obs.).

220 The broad physiological tolerance of adult $C$. mutica would suggest that changing 221 temperature and salinity conditions experienced during transport through equatorial or 222 polar regions would be unlikely to adversely affect individuals in ballast water (Witt 223 et al., 1997) or on ships' hulls (Minchin and Gollasch, 2003). Species distributions 224 that are limited by thermal tolerances are expected to change in response to climate 225 change (e.g. marine mammals, Tynan \& DeMaster, 1997; coral reefs, Hoegh226 Guldberg, 1999; pelagic ecosystems, Boyd \& Doney, 2002). Predicted rates of range 227 expansion in terrestrial environments include $6.1 \mathrm{~km}$ per decade (Parmesan \& Yohe, 228 2003) and $12.5-24.8 \mathrm{~km}$ per decade (Hickling et al., 2006). In particular, evidence 229 suggests that many invasive species possess traits that will enable them to capitalize 230 on the various elements of global change, exacerbating the impacts of invasions on 231 stressed ecosystems (Dukes \& Mooney, 1999). Climate change will be important in 232 determining the future distribution of C. mutica, which can be expected to extend 233 polewards.

234 In addition to environmental conditions, the success of non-native species is also 235 influenced by the frequency of introduction events, which are generally more 236 common in temperate waters (Minchin \& Gollasch, 2003; Drake \& Lodge, 2004) 
237

238

239

240

241

compared to tropical or polar regions, propagule pressure (the frequency and size of introduction events), and biotic interactions in the recipient region such as competition, facilitation and predation (Bruno et al., 2005). Thus, the current distribution of C.mutica is likely to reflect a combination of introduction opportunities, as well as favourable abiotic and biotic conditions in these areas.

Broad physiological tolerance and plasticity are commonly cited as characteristics of successful invading species (Van der Velde et al., 1998), with temperature and salinity tolerances often combining to limit the potential distributions of marine species (Wiederholm, 1987; Stauffer \& Boltz, 1994). Given the broad temperature and salinity tolerance of adult $C$. mutica observed in this study, the caprellid is likely to be limited to marine habitats experiencing a temperate climate (not exceeding $26^{\circ} \mathrm{C}$ ), and regions where salinity does not drop below 18 for extended periods of time. Evidence suggests that dispersal via human vectors is increasing the distribution of $C$. mutica at a faster rate than climate change (Ashton, 2006). Therefore, at present human dispersal will be the most important factor in determining the range expansion of C. mutica.

\section{Acknowledgements}

We thank A. Keay for help with the experimental setup and H. Brown and R. Shucksmith for assistance with field collection of $C$. mutica. This work was funded through a PhD studentship by the UK Natural Environmental Research Council (NER/S/A/2003/11899). 
261

262 263

264

265

266

267

268

269

270

271

272

273

274

275

276

277

278

279

280

281

282

283

284

285

\section{References}

Ashton, G.V. (2006) Distribution and dispersal of the non-native caprellid amphipod, Caprella mutica Schurin 1935. Unpublished PhD Thesis. Scottish Association for Marine Science, Oban, Scotland.

Ashton, G.V., Willis, K.J., Cook, E.J., Burrows, M.T. (in press) Distribution of the introduced amphipod, Caprella mutica Schurin on the west coast of Scotland and a review of its global distribution. Hydrobiologia, in press.

Boyd, P.W. \& Doney, S.C. (2002) Modelling regional responses by marine pelagic ecosystems to global climate change. Geophysical Research Letters, 29, 5356.

Bruno, J.F., Fridley, J.D., Bromberg, K.D., Bertness, M.D. (2005) Insights into Biotic Interactions from Studies of Species Invasions. In: Sax D.F., Stachowicz, J.J., Gaines, S.D. (eds). Species invasions. Insights into ecology, evolution and biogeography. pp. 13-40. Sinauer Associates, Inc. Publishers. Sunderland, Massachusetts.

Cockman, B. \& Albone, P. (1987) Caprellidae of the Swan River Estuary. In: John J (ed). Swan River Estuary, Ecology and Management. Curtin University, Environmental Studies Group Report no. 1. pp.163-177. Curtin University of Technology, Perth, Australia.

Davenport, J. \& Davenport, J.L. (2005) Effects of shore height, wave exposure and geographical distance on thermal niche width of intertidal fauna. Marine Ecology Progress Series, 292, 41-50.

Drake, J.M. \& Lodge, D.M. (2004) Global hot spots of biological invasions: evaluating options for ballast-water management. Proceedings of the Royal Society of London B, 271, 575-580. 
286 Dukes, J.S. \& Mooney, H.A. (1999) Does global change increase the success of 287 biological invaders? Trends in Ecology \& Evolution, 14, 135-139.

288 Finney, D.J. (1971) Probit Analysis. 3rd edn. Cambridge University Press, $289 \quad$ Cambridge.

290 Hamilton, M.A., Russo, R.C., Thurston, R.V. (1977) Trimmed Spearman-Karber 291 method for estimating median lethal concentrations in toxicity bioassays. 292 Environmental Science and Technology, 11, 714-719.

293 Hickling, R., Roy, D.B., Hill, J.K., Fox, R., Thomas, C.D. (2006) The distributions of 294 a wide range of taxonomic groups are expanding polewards. Global Change 295 Biology, 12, 450-456.

296 Hoback, W.W. \& Barnhart, M.C. (1996) Lethal limits and sublethal effects of hypoxia 297 on the amphipod Gammarus pseudolimnaeus. Journal of the North American Benthological Society, 15, 117-126.

299 Hoegh-Guldberg, O. (1999) Climate change, coral bleaching and the future of the 300 world's coral reefs. Marine and Freshwater Research, 50, 839-866.

301 Kinne, O. (1970a) Salinity: Animals: Invertebrates. Marine ecology, vol. 2. (ed. by 302 Kinne, O.), pp. 821-995. Wiley-Interscience, London,

303 Kinne, O. (1970b) Temperature: Animals: Invertebrates. Marine ecology vol. 1. (ed. 304 by Kinne, O.), pp. 407-514. Wiley-Interscience, London, 305 Laubitz, D.R. (1970) Studies on the Caprellidae (Crustacea, Amphipoda) of the American North Pacific. National Museum of Canada.

307 Minchin, D. \& Gollasch, S. (2003) Fouling and ships' hulls: how changing 308 circumstances and spawning events may result in the spread of exotic species. $309 \quad$ Biofouling, 19, 111-122. 
310 Parmesan, C. \& Yohe, G. (2003) A globally coherent fingerprint of climate change 311 impacts across natural systems. Nature, 421, 37-42.

312 Schevchenko, O.G., Orlova, T.Y., Maslennikov, S.I. (2004) Seasonal dynamics of the 313 diatoms of the genus Chaetoceros Ehrenberg in Amursky Bay (Sea of Japan). 314 Russian Journal of Marine Biology, 30, 11-19.

315 Sprague, J.B. (1963) Resistance of four freshwater crustaceans to lethal high 316 temperature and low oxygen. Journal of the Fisheries Research Board of $317 \quad$ Canada, 20, 388-415.

318 Stauffer, J.R. \& Boltz, S.E., (1994) Effect of Salinity on the Temperature Preference 319 and Tolerance of Age-0 Mayan Cichlids. Transactions of the American $320 \quad$ Fisheries Society, 123, 101-107.

321 Strasser, M. (1999) Mya arenaria - an ancient invader of the North Sea coast. Helgoländer Meeresuntersuchungen, 52, 309-324.

323 Tait, R.V. (2001) Elements of Marine Ecology. Butterworth Heinemann, Oxford.

324 Takeuchi, I., Matsumasa, M., Kikuchi, S. (2003) Gill ultrastructure and salinity 325 tolerance of Caprella spp. (Crustacea: Amphipoda: Caprellidae) inhabiting the 326 Sargassum community. Fisheries Science, 69, 966-976.

327 Thiel, M., Guerra-Garcia, J.M., Lancellotti, D.A., Vasquez, N. (2003) The distribution 328 of littoral caprellids (Crustacea: Amphipoda: Caprellidea) along the Pacific 329 coast of continental Chile. Revista Chilena de Historia Natural, 76, 297-312.

330 Tynan, C.T., DeMaster, D.P. (1997) Observations and predictions of Arctic climate 331 change: potential effects on marine mammals. Arctic, 50, 308-322.

332 U.S.E.P.A. (1990) Trimmed Spearman-Karber (TSK) Program Version 1.5. 333 Ecological monitoring research division, Environmental monitoring systems 
laboratory, U. S. Environmental Protection Agency, Cincinnati, OH. (Available online at http://www.epa.gov/nerleerd/stat2.htm).

336 Van der Velde, G., Rajagopal, S., Kelleher, B., Muskó, I.B., bij de Vaate, A. (1998) Ecological impact of crustacean invaders: General considerations and examples from the Rhine River. Crustacean Issues, 12, 3-33.

Vermeij, G.J. (1996) An agenda for invasion biology. Biological Conservation, 78, 3-

9.

341 Wiederholm, A.-M. (1987) Distribution of Potamoschistus minutus and P. microps (Gobiidae, Pisces) in the Bothnian Sea: importance of salinity and temperature. Memoranda Soc. Fauna Flora Fennica, 63, 56-62.

344 Witt, J.D.S., Hebert, P.D.N., Morton, W.B. (1997) Echinogammarus ischnus: another 
Figure Legends

350

351 Figure 1. Mortality of C. mutica following $48 \mathrm{~h}$ exposure to temperatures between 21 and $30{ }^{\circ} \mathrm{C}\left(\right.$ mean \pm S.E., $\mathrm{n}=3$ ). Reference lines indicate $48 \mathrm{~h} \mathrm{LT}_{50} \pm 95 \% \mathrm{CI}$ (broken lines) estimated using TSK analysis.

355 Figure 2. Mortality of $C$. mutica following $48 \mathrm{~h}$ exposure to salinities between 9 and 20 (mean \pm S.E., $\mathrm{n}=3$ ). LC indicates lethal concentration of percentile mortalities; the broken reference line indicates the lower $48 \mathrm{~h} \mathrm{LC}_{50}$ (estimated using Probit analysis). 


\section{ACCEPTED MANUSCRIPT}

359

360

361 Figure 1.

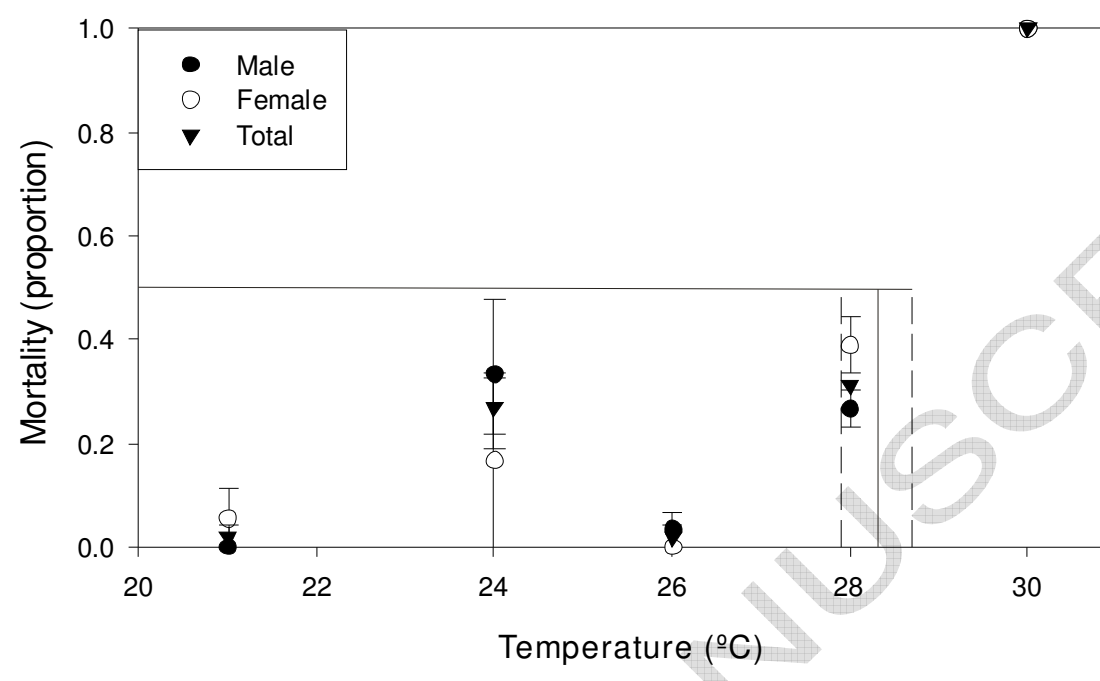

362

363 


\section{ACCEPTED MANUSCRIPT}

363

364 Figure 2.

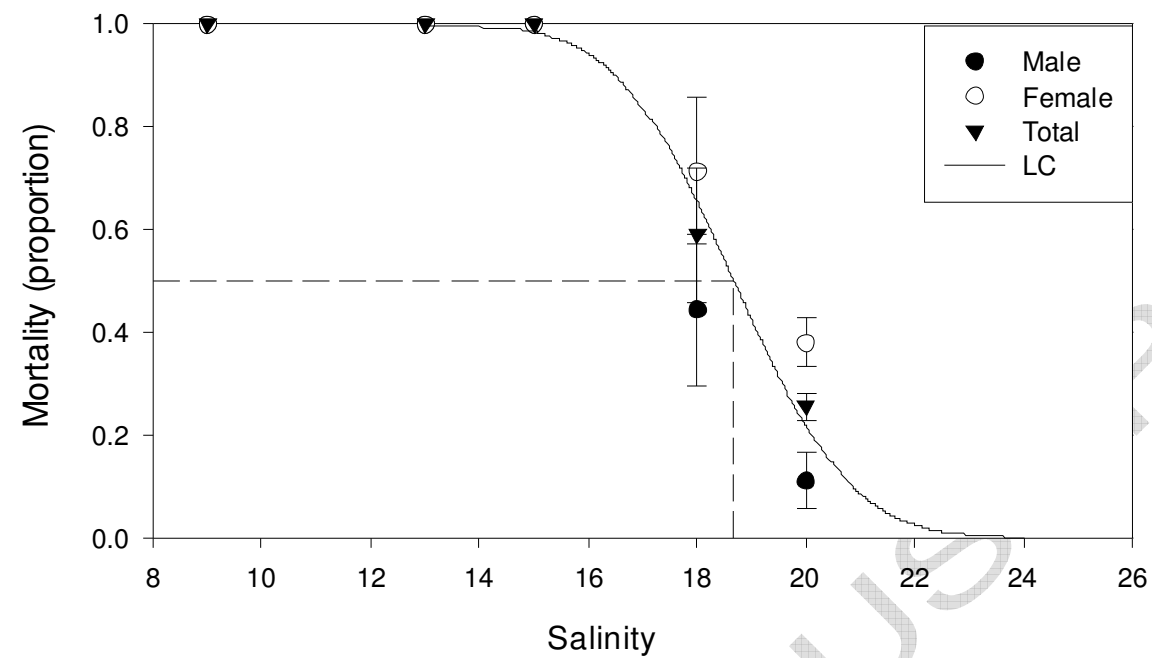

365

366

367 